STUDIA ROSSICA POSNANIENSIA, vol. XL, cz. 1: 2015, pp. 77-81. ISBN 978-83-232-2878-3. ISSN 0081-6884.

Adam Mickiewicz University Press, Poznań

\title{
OBRAZ INTELIGENCJI W PARODYJNYM ŚWIETLE NA PODSTAWIE POWIEŚCI KROKODYL WŁODZIMIERZA KANTORA
}

\author{
A PARODY OF THE INTELLIGENTSIA \\ IN VLADIMIR KANTOR'S CROCODILE
}

\author{
AGNIESZKA TRACZ
}

\begin{abstract}
This article describes a parody of the Russian intelligentsia in the 1970s. It also discusses the motif of a crocodile in Russian culture, i.e. Pomadov and Oblomov, and a longing for freedom. It also aims to show the atrocities of everyday life.
\end{abstract}

Agnieszka Tracz, Uniwersytet im. Adama Mickiewicza w Poznaniu, Poznań - Polska.

Włodzimierz Kantor to znamienity rosyjski pisarz, literaturoznawca, profesor filozofii, myśliciel współczesnego świata i autor wielu traktatów teoretycznych. Pisarz podejmuje niezwykle istotne i aktualne tematy, a mianowicie „rozkład” rosyjskiego społeczeństwa, jego zalety i wady. To właśnie Kantor potrafi "odrzeć” jednostkę ludzką z wszelakich słabości, przywar. Dlatego też tworzy on przenikliwe powieści, w których przeplatają się brutalna rzeczywistość z fantastyką, psychologia z filozofią i powaga z parodią.

Zdaniem współczesnych krytyków literackich Kantor to mistrz parodii, baczny obserwator psychiki ludzkiej i dosadny moralista. W związku z tym na jego twórczość zwróciło uwagę wielu wybitnych literaturoznawców, takich jak: A. Radczenko, B.W. Tomaszewski, N.I. Iwanowa, A. Wołkow i M.M. Makowski, jednomyślnie stwierdzając, iż twórczość tegoż pisarza to majstersztyk naszych czasów ${ }^{1}$. Również nie dziwi ich fakt, że Kantor jest laureatem nagrody Heinricha Bölla, a według francuskiego czasopisma „Le Nouvel Observateur" zaliczany jest do 25 największych myślicieli tego świata (25 grands penseurs du monde entier) ${ }^{2}$. Natomiast w $2009 \mathrm{r}$. pisarzowi wręczono nagrodę „Золотая Вышка” za niezwykłe osiągnięcia w dziedzinie nauki. Do jego spuścizny literackiej zaklasyfkowano takie

1 П. Л а д о х и н, Настоящее русской литературы, „Знамя” 2004, № 3, s. 1.

2 К. К а л о м е н с к и й, Кантор-мастер, [w:] źródło elektroniczne: http://ola.russ.ru/ krug/kniga/20021021_lius-pr.htm (23.03.2012). 
powieści jak: Krokodyl (Крокодил), Dwa domy (Два дома) czy Sto dolarów (Cmo долиаров).

Kantor jako mistrz obserwacji w swojej twórczości posługuje się parodią, gdyż chce przestrzec czytelnika przed problemami XX wieku, uwrażliwić go na te kwestie i objaśnić absurdalne mechanizmy rządzące naszym światem. W związku z tym literaturoznawca postanowił przedstawić parodyjność inteligencji w swojej powieści pt. Krokodyl.

Podobne kroki podjęli inni rosyjscy pisarze, kreśląc swoiste obrazy inteligencji rosyjskiej. Powyższa kwestia poruszyła wspaniałych pisarzy, takich jak: Iwan Bunin, Michaił Bułhakow i Fiodor Dostojewski. Zwrócili oni szczególną uwagę na inteligencję - z tego względu, iż jest ona związana z socjalno-politycznymi kryzysami, a co ważne, mało który człowiek w inteligencie widzi "swojego" człowieka ${ }^{3}$. Pisarze skupili się nie tylko na opisie zalet i wad inteligencji, ale także zagłębili się w duszę inteligenta, dokonali jego analizy psychologicznej, dowiedzieli się, jaka jest moralność tego typu człowieka oraz jego światopogląd. Bunin, Bułhakow czy Dostojewski próbowali nakreślić czytelnikowi kilka typów inteligentów, więc podzielili ich na ludzi dobrych i złych, świadomych i nieświadomych swoich postępków, rozsądnych i nierozsądnych oraz szlachetnych i nieszlachetnych.

W powieści zatytułowanej Krokodyl Włodzimierz Kantor również przedstawia inteligencję $\mathrm{w}$ niezwykle charakterystyczny sposób. Pisarz uwypukla tu obraz inteligencji w parodyjnym świetle, ośmieszając czy wytykając tej klasie społecznej gnuśność, bezradność i niepohamowane pijaństwo.

Krokodyl to powieść o pijącej inteligencji. Dlatego też opary alkoholowe towarzyszą czytelnikom niemalże w każdym rozdziale książki. Pić czy nie pić? Takie pytanie nurtuje postaci powyższej powieści.

Głównym bohaterem Krokodyla jest Lowa Pomadow, 48-letni mężczyzna, który jest w pełni zadowolony z siebie. Co więcej, jest nazywany Hamletem naszego życia, a „Popijawę z przyjaciółmi czy nawet przypadkowymi biesiadnikami przedkładał nad karierę, więc przehulał swoje możliwości"4. Pomadow miał grono swoich znajomych, którzy posiadali tytuły naukowe. Sam zaś nie miał żadnego tytułu, albowiem uważał, że jest to rzecz zbyteczna, całkowicie niepotrzebna w życiu. Lowa dochodzi do śmiałego wniosku, że jest twórcą kalejdoskopu-zabawki z umieszczonymi w niej ruchomymi szkiełkami bądź zwierciadłami, które przy poruszaniu układają się w różnego rodzaju figury ${ }^{5}$. Drugie dno, przenośne znaczenie kalejdoskopu polega na tym, iż wszystkie obrazy lub wydarzenia następują szybko po sobie, dając efekt wielości, barwności czy też szeroko pojętej

\footnotetext{
3 Ф. М е с к и й, Мойдодыр, „Знамя" 2004, № 18, s. 7.

${ }^{4}$ W. K a n t o r, Krokodyl, Warszawa 2007, s. 10.

5 S. M a c i e j e w s k i, Kalejdoskop, „Era” 2001, nr 5, s. 14.
} 
zmienności. Pomadow twierdzi, że życie podlega nieustannym zmianom i że człowiek ma na to wpływ. Jak sam mówi, „Do głowy nie przychodziło nic sensownego poza wczorajszym porównaniem życia do kalejdoskopu"6. Lowa chce napisać rozprawę o tym, że człowiek może zmieniać swoje życie. Mimo iż prowadził z kolegami absurdalne dysputy i dochodził do równie absurdalnych wniosków, nie można go nazwać nieudacznikiem, gdyż był lubiany, cieszył się powodzeniem u kobiet.

W Krokodylu niby wszyscy pili, ale pijaństwo dla głównej postaci to sposób rozmowy, rozmyśleń czy też nawet sposób filozoficzny, a „pijacki animusz nieco dodawał mu sił"7. Dlatego Kantor naśmiewa się z tej przywary inteligencji, ale też odnajduje i podkreśla parodyjność $\mathrm{w}$ zachowaniu inteligentów, kiedy Pomadow, nie chcąc się przemęczać, skraca artykuł dla leniwych profesorów.

W powyższym utworze przejawiają się elementy Zbrodni $i$ kary w kontekście dysputy i miłości do alkoholu. Alkohol w utworze Dostojewskiego daje "radość”, bowiem Marmieładow, ojciec Soni, jest alkoholikiem, ale z tego względu jego córka przechodzi przemianę duchową, "oddając" się Chrystusowi poprzez czytanie Biblii.

Pomadow w powieści Kantora pije, bo wie, iż w narodzie panuje „тоска-маразм", a to daje ogromny smutek, brak nadziei na lepsze jutro. Z tego względu, że ów naród był obciążany przez wieki niewolą tatarską: paleniem domów, zabijaniem niewinnych ludzi, przemocą.

Epicentrum powieści stanowi nagłe spotkanie w windzie Pomadowa z krokodylem. W metaforycznym ujęciu ten krokodyl jest ostrzeżeniem dla alkoholika z delirium tremens. Pisarz „uczłowiecza” tę dziką bestię. Lowa nie jest zadowolony ze spotkania i boi się tego, ale mimo to próbuje się „zaprzyjaźnić" z potworem. Krokodyl był ogromny, obślizgły, śmierdzący, a z pyska czuć było niestrawione mięso: „Potem ten ktoś, ta ogromna masa o gorącym, smrodliwym oddechu, nie wiedzieć czemu zalatująca zapachem trzciny, błota, ryby i czegoś oślizgłego, zagrodziła Lowie drogę i przycisnęła do ściany..." 8 . Można to odczytać jako metaforę okrutnej rzeczywistości rosyjskiej, której również nie można ani strawić, ani znieść.

Lowa w swoim życiu popełnił sporo błędów. Miał trzy żony. Pierwszą zmusił do aborcji, więc śmiało można to zinterpretować w ten sposób, iż „pożarl” swoje dziecko i wciela się w rolę groźnego krokodyla. Życie Pomadowa nie jest osamotnione, ponieważ na każdym kroku spotyka go Mojdodyr, który jest zapożyczony od głównego bohatera bajki w wierszach Czukowskiego. W tej bajce chłopca odwiedza Mojdodyr, stanowiący wezwanie do przestrzegania zasad higieny przez dziecko. Owa postać wywołuje

\footnotetext{
${ }^{6}$ W. K a n t o r, op. cit., s. 31-32.

7 Tamże, s. 206.

8 W. K a n t o r, op. cit., s. 34.
} 
w maleńkim człowieku ogromny strach, tak jak przerażający potwór Kantora. Dlatego też Krokodyl to alter ego głównej postaci ${ }^{9}$. Lowa postanawia uciec od Mojdodyra, lecz w żółtych oczach odrażającego monstrum zauważa istotne powiedzenie: „Od siebie nigdy nie uciekniesz”.

Kantor podejmuje się wyjaśnienia pojęcia rosyjskiej krokodyliady, która jest równoznaczna z alkoholowym upiorem, posiadającym niezwykłą moc rozgrzeszania ludzi i rozjaśniania im umysłów. W polskiej kulturze alkoholicy widzą białe myszki, a w rosyjskiej krokodyla - z tego względu, że jest on ogromny, przerażający i jest symbolem strachu. Dzięki temu pisarz parodiuje brutalną rzeczywistość. Ale czemu to ma służyć? Zapewne chce dotrzec do samoświadomości Rosjan. W ten sposób starano się ujarzmić, przezwyciężyć ciężką rzeczywistość. Tak samo dzieje się w przypadku krokodyla, którego trudno jest oswoić. Rosjan przekonywano do tego, iż taką bestię da się udomowić, więc była to rosyjska bajka o krokodylu Leopoldzie. Krokodyl to bajka napisana przez Czukowskiego w latach 1916-1917, będąca zwierciadłem rewolucji (1905-1907) i przedstawiająca okrucieństwo tamtych czasów, tak bardzo niepojęte dla dziecka.

Nieodłącznym elementem powieści Kantora jest motyw bagna, który jest synonimem życia Lowy. Ten motyw pojawił się, gdy syn przyjaciela Pomadowa utopił się w bagnie lub ktoś przyczynił się do tego, ale tak naprawdę tego zajścia nikt nigdy nie rozszyfrował. Bagno w tym utworze jest również odwołaniem do Moskwy, która została wybudowana na osuszonych terenach ${ }^{10}$. Bohaterowie Krokodyla są związani z terenami bagiennymi, jak i to zwierzę, w związku z tym należą oni do postaci negatywnych.

W ostateczności czym lub kim jest krokodyl z bagien? Czy to zjawa? Czy to marazm? Czy zwykły skutek pijaństwa? A może to gryzący wyrzut sumienia? A może Krokodyl to wynik Sądu Bożego lub Lewiatan? W Biblii Lewiatan był w pierwszym szeregu aniołów, natomiast pierwotnie jest on kojarzony ze złem, i tu pojawia się dwuznaczność11. Z kolei Krokodyla można odnaleźć w żartobliwych anegdotach na kartach powieści, a Pomadow próbuje dociec, dlaczego właśnie to zwierzę tak "zagnieździło się" w samoświadomości Rosjan?

Władimir Kantor jako wybitny myśliciel, filozof przyczynia się do powstania takiego pojęcia jak pomadowszczyzna, które nawiązuje do obleśnego, leniwego szlachcica Obłomowa z powieści Gonczarowa ${ }^{12}$ i powstałego w XIX wieku określenia obłomowszczyzny, symbolizującej specyficzny, leniwy sposób na życie. Określenie pomadowszczyzna zostało utworzone od

${ }^{9}$ D. A r k o w, Twórczość Włodzimierza Kantora, „Era” 2002, nr 16, s. 7.

${ }^{10} Г$. Н а у м о в а, ВЛАДИМИР КАНТОР: Сокрушитель Варварства, „Литературные статьи" 2001, № 8, s. 12.

${ }^{11}$ K. N o w a k, Kantor, "Zwierciadło" 2000, nr 16, s .4.

12 L. R e i c h, Kantor, "Filozofia” 2008, nr 10, s. 7. 
imienia głównego bohatera - Pomadowa. Jego koledzy stworzyli takie pojęcie, aby odpowiednio określić zachowanie postaci, jej sposób bycia. Pomadowszczyzna jest kwintesencją bohatera, gdyż w sposób dosadny określa jego rozum, pochodzenie z rodziny inteligentów. Lowa zmarnował swoją szansę na rozwój, stał się człowiekiem leniwym, gburowatym, pod wpływem alkoholu nieuprzejmym, nietolerancyjnym. Pomadow jest zadowolony ze swojego życia, ponieważ jest niesamowicie gnuśny, zafascynowany alkoholem i pogodzony z faktem, że obcuje ze straszliwym krokodylem.

Powyższe negatywne cechy inteligencji zostały zebrane w całość i przedstawione po to, aby przedstawić tę klasę społeczną w parodyjnym świetle, akcentując takie zjawiska jak:

- маразм = тоска,

- bezmyślność,

- lenistwo,

- pijaństwo,

- obcowanie z alkoholowym demonem (krokodylem),

- życie w pułapce ${ }^{13}$.

Niewątpliwym atutem Krokodyla jest fakt, że powieść ta nie opisuje procesu rozwoju socjalizmu, lecz traktuje o prawdziwym życiu inteligencji, bez afirmacji. Kantor, stosując reakcję łańcuchową ludzkich zachowań, udowadnia czytelnikom, jak czyny istoty ludzkiej potrafią wpłynąć na jej życie i życie innych. Pisarz definiuje również pojęcie zła, które jest dla niego wykładnikiem samooczyszczenia. Co więcej, stara się pokazać, że człowiek jest tylko człowiekiem.

Możemy mieć nadzieję, że zastosowana w powieści Krokodyl parodyjność przyczyni się do lepszego zrozumienia radzieckiej inteligencji, jej przegranego życia i praw rządzących tym owianym alkoholowymi oparami światem.

\footnotetext{
${ }^{13}$ M. 3 а г и д у л и н а, Гамлет vs Мойдодыр, „Знамя" 2003, № 6, s. 240.
} 
